\title{
Influencing Factors Research of Logistics Park Planning
}

\author{
Susheng Zheng \\ Scientific Research Office, Jiangxi University of Technology
}

Keywords: Logistics parks; Development status; The location; Overall layout

\begin{abstract}
With the rapid development of modern logistics industry globally, planning and construction of the logistics park is considered to be an important breakthrough to promote the development of modern logistics. During the planning process of logistics park, the layout and the location function are taken as the important and fundamental parts that are affecting the overall development of logistics parks. Logistics park is the product of modern logistics industry when it has develops to a certain period, and is also known as the logistics regiment, which is both a major carrier and an important direction of modern logistics development. However, the planning and construction of logistics parks is a huge systematic engineering, and during construction and operation, it will inevitably have some problems. The development of the logistics industry in China has been accompanied by the blind construction of logistics parks, therefore, it is needed to actively promote the study of logistics park location and the overall layout.
\end{abstract}

\section{Introduction}

With the rapid development of the world economy, the logistics industry has not only become a magic weapon to promote China's economic development, but also a "profit source" of cost savings for many business. Since logistics park is the product of modern logistics industry when it has develops to a certain period, in recent years, it has caught widespread attention at all levels of government and the community. In this process, there are blind construction problems of logistics parks: lacks of scientific planning, unreasonable construction, low occupancy rate and high vacancy rate all have brought a tremendous waste of resources. Therefore, it is necessary to conduct the research of location and planning of logistics park .

Through the network and field research, as well as the basic theoretical knowledge of the logistics park, the paper has conducted an in-depth study of logistics parks planning and construction nationwide, and put forward the shortcomings of China's modern logistics parks in terms of construction. At last, the paper has combined its research and proposed some constructive suggestions.

\section{Main Problems Existing in Logistics Parks Planning and Construction}

Macro pe rspective. The lack of scientific needs analysis: The key of logistics parks construction requirements, locations, scale, and function lies in the need of market demand and business. Though government has actively built logistics parks of all sizes, the attitude of companies is not positive. There is no scientific or in-depth analysis of local economic development status, ignoring the investigation and analysis of the logistics market demands . 
The reasons of being lack of scientific and rational planning are as follows. On the one hand, the government's starting point fails to correspond to real market economy status; on the other hand, a lot of logistics parks become the government's image projects with a mandatory construction, expansion and migration.

Order-less management system and redundant construction: Instead of developing logistics from the aspect of improving the operational efficiency of logistics enterprises, and enhancing the overall economic efficiency, some planning and construction of logistics parks have failed to fully utilize the logistics resources during the construction process.

Noneffective logistics parks management: The services provided by most of the domestic logistics parks service are only limited to the warehouse and freight yard rental, or the logistics facilities and equipment leasing, which have no great difference from traditional warehousing industry. Therefore, it cannot meet the needs of different customers.

Relatively weak policy and legislation: The production of China's logistics park is based on the rapid development of the logistics industry, but it has encountered issues such as imperfect regulatory mechanism, and the lack of supporting policy as we 11 as the legal environment in its process of rapid development; therefore, to promote rapid and healthy development of logistics parks, it is required a macro-policy guiding role of government at all levels, so as to create a favorable macro environment.

Micro pe rspective. (1) Location: during the the location selection process, one should take the convenience of transportation, the proximity to the market and the companies into account .

(2) Cost: high land prices would increase cost of construction, affecting the investment ratio throughout the building and leading to the difficulties in construction process.

(3) Environment: the location selection should also pay attention to environmental issues; harsh environment around the park will accelerate the aging of the goods; construction of the park will also have some impact on the surrounding environment, including road transport, household, ecological environment and so on.

\section{Factors affecting logistics park location and general layout}

Factors Affecting Logistics Park Location. Natural Environment. Meteorological conditions: in the location selection process, weather conditions to be considered include temperature, humidity, precipitation, wind, frost-free period, frozen soil depth and so on.

Geological conditions: logistics park is a staging ground for a large number of goods, and some piled up materials with great mass would impose certain amount of pressure onto the ground, for which it requires the ground have sufficient bearing capacity.

Hydrological conditions: the location selection should stay away from easily flooding river basin and groundwater overflow areas. The hydrological data should be carefully reviewed in recent years: the groundwater level cannot be too high; the flooded area, waterlogging area, fossil river course, and dry river channels should be avoided.

Operating Environment. Business environment: preferential policies of the park have a significant impact on whether logistics enterprises could generate economic benefits or not; meanwhile, sufficient amount and high quality of labor are factors to be considered.

Product features: various types of goods should be stored in different areas, for example, production type logistics park would better take the industrial structure, product structure and industrial layout into closely consideration. 
Logistics costs: Logistics costs is one of the focuses during location selection. Most of logistics parks are close to logistics services high demand areas, in order to shorten transportation distances, reduce freight and other logistics costs.

Infrastructure. Traffic conditions: logistics parks must have convenient transport conditions, i.e. near transportation hubs; such as being close to the port, the main roads, railway or airport and with two or more modes of transport connected with each other.

Public facilities: location of logistics park requires a full range of urban roads, communications and other public facilities with plenty of power, water and gas capacity, and processing capacity of sewage and solid waste.

Factors affecting logistics parks layout. The economic development level of the area or the city. The economic development level of the city is a concentrated representation of its comprehensive strength; as a better-off city, its large production, and consumption amount have increased total logistics demand, and therefore increased the demand for logistics park.

Traffic geographic advantages of the area and the city. Traffic geographic conditions of the city have reflected the urban transport facilities and integrated transport capacity, which are determined by the weighted factors such as the number of airlines, railway lines, river channels, national and provincial roads which are through its territory.

Regional, urban industrial structure. Logistics structure of the city is decided its industrial structure. To serve the regional industrial development is also the aim of logistics park building. Therefore, the industrial structure has also determined the features of regional logistics parks to be established.

\section{Conclusions}

In China, the $21^{\text {st }}$ century will be a rapid development period of logistics industry, which will have a huge impact on China's social progress and economic development, including the impact on the economic structure and the impact on the urban space development. All these make planning location selection of the logistics park be particularly important. There is rich experience in the planning and construction of logistics parks in the developed countries; however, in China, the study on the logistics park planning has yet to rise, and there are little relevant theoretical monographs and articles; moreover, they have a lot of repetition in the content.

The research on logistics infrastructure and a single logistics center is comparatively more, but these location models are not strong in applicability, not theoretically well-grounded in terms of location selection and the size determination. The practices and research of logistics parks planning just began in recent years. This paper has summarized the experience of domestic and international logistics park planning and construction, conducted in-depth analysis of various factors affecting the siting and construction of logistics park combined with case studies of Shenyang Economic Zone Layout, for the purpose of calling for the attention to the planning and construction of logistics park, enhancing planning, development, management awareness of the logistics park, so as to ensure its scientific rationality.

\section{References}

[1] Zhao Xu. Research on China's logistics park planning and siting [D]. Dalian Maritime University, 2007. 
[2] Liu Nana. Logistics park location planning and construction program [D]. Shandong University of Science and Technology, 2011.

[3] Wang Jie. Toughts about the current situation of China's logistics parks development [J]. Logistics Technology, 2007 (8).

[4] Dong Zhongmin. Problems and countermeasures research on logistics parks development in Shenyang. [J]. Chinese market, 2008 (15).

[5] Yang Yanhai. Shenyang logistics park development countermeasures [J]. Logistics Engineering and Management, 2010.

[6] Xie Boping. Analysis of regional logistics park general layout planning methods [J]. Communication Science and Technology, 2010, (3).

[7] Jing Ying. Logistics Park Location Analysis [D]. China Logistics and Purchasing, 2010, (6).

[8] $\mathrm{Wu}$ Hong. Inspiration and Reflections on typical domestic and foreign logistics parks construction [J]. Logistics Technology 2013. (10).

[9] Zhang Jun. Research on Yanji logistics park location and scale determination [D]. Jilin University, 2011.

[10] Lijuan Huang. Modeling and Planning on Urban Logistics Park Location Selection Based on the Artificial Neural Network [J]. Journal of Computers, 2012, Vol.7 (3), pp.792-797.

[11] Hui Yue, Wenyu Yue, Xiaoqiang Long. Engineering Evaluation System of Logistics Park Capability [J]. Systems Engineering Procedia . 2011.45-49 